\title{
ABORIGINAL RIGHTS AND CANADIAN SOVEREIGNTY: AN ESSAY ON R. v. SPARROW
}

\section{MICHAEL ASCH* and PATRICK MACKLEM**}

The authors articulate the basic elements of two competing theories of aboriginal right. The first, $a$ contingent rights approach, requires state action for the existence of aboriginal rights. This approach dominated early judicial pronouncements on the nature of aboriginal rights. The second, an inherent rights approach, views aboriginal rights as inherent in the nature of aboriginality. This approach came to be embraced by the judiciary in cases addressing the nature of aboriginal legal interests prior to the passage of the Constitution Act, 1982. The authors then assess the Supreme Court of Canada's decision in R. v. Sparrow in light of these two competing theories. In Sparrow, the Court addressed the meaning of s. 35(1) of the Constitution Act, 1982 and, despite other laudable aspects of the judgment, relied on a contingent theory of aboriginal right and an unquestioned acceptance of Canadian sovereignty. The authors offer two alternative approaches to $s$. $35(1)$ based on the overarching value of equality of peoples. As a result, the Court severely curtailed the possibility that s. 35(I) includes an aboriginal right to sovereignty and rendered fragile $s$. 35(I)'s embrace of a constitutional right to self-government.
Les auteurs définissent les éléments essentiels de deux theories concurrentes des droits des peuples autochtones, la première traite de droits éventuels et requiert un acte de l'État. Cette approche a dominé les premiers jugements portant sur la nature des droits des peuples autochtones. La seconde traite de droits inhérents et perçoit les droits comme inhérents d la qualité d' "autochtone". Cette approche a été adoptée par le pouvoir judiciaire dans les cas traitant de la nature des intérêts légaux des autochtones avant l'adoption de la Loi constitutionnelle de 1982. Les auteurs évaluent ensuite la décision de la Cour suprême du Canada dans la cause R. c. Sparrow d la lumière de ces deux théories. Dans Sparrow, la Cour traite de la signification de l'article 35 (l) de la Loi constitutionnelle de $1982 \mathrm{et}$, malgré les autres aspects louables du jugement, s'en remet à la théorie des droits éventuels et d l'acceptation incontestée de la souveraineté canadienne. Il s'ensuit que la Cour a sévèrement restreint la possibilité que l'article $35(1)$ inclue le droit des autochtones a la souveraineté et qu'il amenuise l'engagement de l'article $35(1)$ envers un droit constitutionnel d l'autonomie. Les auteurs offrent deux approches possibles à l'article 35(1), lesquelles sont fondées sur la valeur primordiale de l'égalité des peuples.

\section{TABLE OF CONTENTS}

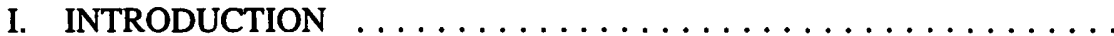

II. TWO THEORIES OF ABORIGINAL RIGHT

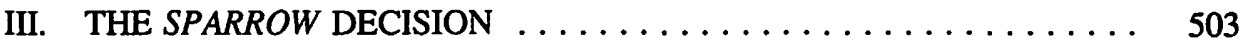

IV. SOVEREIGNTY AND THE SETTLEMENT THESIS $\ldots \ldots \ldots \ldots \ldots 508$

V. TWO ALTERNATIVES $\ldots \ldots \ldots \ldots \ldots \ldots \ldots \ldots \ldots \ldots \ldots, 512$

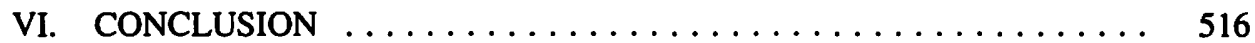

- Department of Anthropology, University of Alberta.

* Faculty of Law, University of Toronto.

The authors wish to thank Steve Greymorning, Kent McNeil, John Olthuis, Chris Printup and Richard Spaulding for their assistance and comments in the preparation of this essay. 


\section{INTRODUCTION}

In a number of important judgments in recent years, the Supreme Court of Canada has sought to address and clarify Canada's legal responsibilities to aboriginal peoples. In Guerin v. The Queen, for example, the Crown was held to be under a fiduciary obligation to aboriginal people with respect to its dealings with surrendered native land. ${ }^{1}$ In Simon $v$. The Queen, treaty rights were given "a fair, large and liberal construction in favour of the Indians." ${ }^{2}$ In $R$. v. Sioui, the Court acknowledged relations between European powers and First Nations at the time of colonial expansion were "very close to those maintained between sovereign nations," and that agreements between the Crown and First Nations are "sacred" and "solemn." ${ }^{3}$ These and other ${ }^{4}$ cases have provided and no doubt will continue to provide important legal arguments to First Nations seeking to better their legal position with the Canadian state in the future.

None of these developments, however, matches the importance of the Court's judgment in $R$. v. Sparrow, ${ }^{5}$ rendered in May of 1990. In Sparrow, the Court for the first time ${ }^{6}$ addressed the scope and content of s. 35(1) of the Constitution Act, 1982, which provides that "existing aboriginal and treaty rights are hereby recognized and affirmed."7 At issue in the case was whether the Musqueam Nation, located in British Columbia, could assert an aboriginal right to fish that would override federal regulations requiring a fishing permit and restricting the method of fishing to the use of a drift net with a maximum length of 25 fathoms. The Musqueam asserted that their right to fish was an "existing" aboriginal right, "recognized and affirmed" by s. 35(1) of the Constitution Act, and therefore paramount over federal law that regulated its exercise. In finding for the Musqueam Nation, the Court, per Dickson C.J. and La Forest J., held that, although Canada enjoys sovereignty over its indigenous population, aboriginal rights that exist at common law are now enshrined in the Constitution by virtue of s. 35(1), and laws that interfere with the exercise of such rights must conform to constitutional standards of justification.

1. (1985), 13 D.L.R. (4th) 321 (S.C.C.), Dickson J.

2. (1986), 24 D.L.R. (4th) 390 (S.C.C.), following Nowegijick v. The Queen (1983), 144 D.L.R. (3d) 193 (S.C.C.), and Jones v. Meehan (1899), 175 U.S. 1 (U.S.S.C.).

3. (1990), 70 D.L.R. (4th) 427 (S.C.C.).

4. See also Mitchell v. Peguis Indian Band (1990), 71 D.L.R. (4th) 193 (S.C.C.), Dickson C.J.'s concurring judgment, at 209 ("If]rom the aboriginal perspective, any federal-provincial divisions that the Crown has imposed on itself are internal to itself and do not alter the basic structure of Sovereign-Indian relations"); and Canadian Pacific Limited v. Paul, [1988] 2 S.C.R. 654 at 677 (Indian title is more than a mere personal right and can compete on an equal footing with other proprietary interests).

5. (1990), 70 D.L.R. (4th) 385 (S.C.C.).

6. At least two cases prior to Sparrow presented the Court with an opportunity to give meaning to s. 35(1): see supra, note 2, and supra, note 3 . In both cases, the Court avoided discussion of s. 35(1).

7. Schedule B to the Canada Act, 1982 (U.K.) 1982, c. 11. 
The Court's reasons in Sparrow no doubt will fuel much academic commentary, for they address numerous fundamental issues surrounding the constitutional relationship between First Nations and the Canadian state. In this essay, we wish to focus on three aspects of the Sparrow case. First, we will explore and assess the underlying theory of aboriginal right embraced by the Court. Second, we will discuss the extent to which the Court in Sparrow laid the foundation for a constitutional right of aboriginal selfgovernment. Third, we will examine the apparent rationale relied on by the Court to contextualize and support the Crown's assertion of sovereignty over the territory that is now Canada. In addressing these issues, we acknowledge that we are retracing ground covered in more detail by others. ${ }^{8}$ However, we hope to offer new insight, albeit tentative, into the nature of aboriginal right and Canadian sovereignty. Equally, we realize that our undertaking is not exhaustive. More extensive treatment by ourselves surrounding these and related issues will appear elsewhere.' Our purpose here is to assess in an exploratory way what appears from the Court's reasons in Sparrow to be the beginnings of a new constitutional framework for understanding aboriginal rights and Canadian sovereignty.

To this end, we have divided this essay into four Parts. In Part I, we outline two competing theories of aboriginal right, and argue that each generates a different legal conception of aboriginal self-government. The first, which has been referred to as a contingent rights approach, ${ }^{10}$ sees aboriginal rights contingent upon formal recognition by legislative or executive authority or explicit constitutional amendment. The second, which has been called the inherent rights approach, ${ }^{11}$ views aboriginal rights as existing independently of the legal creation of Canada and not requiring explicit legislative or executive recognition for their existence. In Part II, we return to $R$. v. Sparrow, and argue that the Court initially embraces an inherent theory of aboriginal right but attempts to avoid one of its implications, namely, a constitutional right to aboriginal sovereignty, by

8. See, for example, B. Slattery, "Understanding Aboriginal Rights" (1987) 66 Can. Bar Rev. 727, and Mei Lin Ng, "First Nations and the Constitutional Right of Self-Govemment" (LL.M. thesis in progress, York University, on file with authors).

9. See M. Asch, "Aboriginal Self-Government and the Construction of Canadian Constitutional Identity" in M. Levin, ed., Ethnonationalism: Canadian and International Perspectives (forthcoming); P. Macklem, "First Nations Self-Government and the Borders of the Canadian Legal Imagination" (1991) McGill L.J. (forthcoming).

10. See, for example, ibid. For a compatible but different use of the term, see J. Whyte, "The Future of Canada's Constitutional Reform Process" (unpublished manuscript on file with authors), at 7 (Supreme Court of Canada jurisprudence views group rights as "contingent, bargained for, and ultimately trumpable").

11. The Assembly of First Nations, for example, proposed the explicit inclusion of an "inherent right of each First Nation to self-govemment" during the 1984 First Ministers' Conference on Aboriginal Constitutional Matters: see Assembly of First Nations, Draft Amendments (unpublished manuscript on file with authors). See also Assembly of First Nations, "Position Paper", in Assembly of First Nations, Our Land, Our Government, Our Heritage, Our Future (Ottawa: AFN, 1990) at 18 (claiming "inherent right" to self-government). See also John Borrows, "A Genealogy of Law: Reconstructing Native Law and Self-Government" (unpublished manuscript on file with authors) ("inherent sovereignty is the first principle in restructuring native society"). 
abruptly switching to a contingent theory of aboriginal right and unquestioningly accepting Canadian sovereignty over its indigenous population. The result is a tentative but extremely fragile commitment to constitutional protection of aboriginal forms of selfgovernment. Part III is devoted to ascertaining possible justifications for the invocation of a contingent theory of aboriginal right and the reasons for the Court's acceptance of Canadian sovereignty, which we locate initially in the Constitution Act, $1867^{12}$ but ultimately in what we call the settlement thesis and colonial beliefs about the superiority of European nations. In Part IV, we return to s. 35(1) of the Constitution Act, 1982, and explore possible alternative approaches premised on an inherent rights approach and a belief in the equality of peoples.

\section{TWO THEORIES OF ABORIGINAL RIGHT}

In 1970, Davey C.J.B.C. wrote the following in Calder v. A.G.B.C. ${ }^{13}$ with respect to the aboriginal rights of the Nishga Nation:

[The Nishga] were at the time of settlement a very primitive people with few of the institutions of civilized society....I have no evidence to justify a conclusion that the aboriginal rights claimed by the successors of these primitive peoples are of a kind that it should be assumed the Crown recognized them when it acquired the mainland of British Columbia by occupation. ${ }^{14}$

Chief Justice Davey's statement is noteworthy in a number of respects. First, as Justice Hall of the Supreme Court of Canada dryly pointed out shortly thereafter, it involves an assessment of aboriginal society "by the same standards that the Europeans applied to the Indians of North America two or more centuries before."15 Second, it implies that aboriginal rights are dependent upon Crown recognition. That is, Chief Justice Davey was of the view that the Nishga Nation could not assert aboriginal title to territory upon which Nishga people hunted, fished and roamed "since time immemorial"16 because of the fact that the Crown did not recognize such a right at the time of European settlement. Third, it assumes that the Crown, and thereafter Canada, acquired territorial sovereignty over British Columbia by "occupation" or, more precisely, settlement. Some or all of these assumptions combine to provide the jurisprudential basis for a contingent theory of aboriginal right.

A contingent rights approach views the existence or non-existence of aboriginal rights to be contingent upon the exercise of state authority. It therefore assumes the legitimacy of executive and legislative authority over First Nations and imagines rights as emanating from state recognition of a valid aboriginal claim to freedom from state interference. An aboriginal right to fish, for example, is dependent upon the state conferring such a right

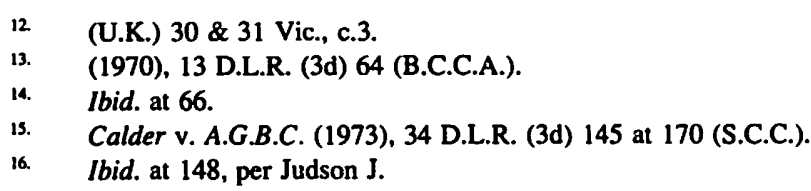


on the relevant aboriginal population by legislative or executive action. An example of the legislative conferral of an aboriginal right is the statutory authorization found in the Manitoba Natural Resources Act, ${ }^{17}$ which provides that "Indians shall have the right ... of hunting, trapping and fishing ... on unoccupied Crown lands." ${ }^{18}$ Provisions in the Royal Proclamation of 1763 protecting aboriginal hunting grounds from settlement are an illustration of prerogative Crown action that confers certain rights on the aboriginal population. In both cases, the presence of the right is imagined by a contingent rights perspective as dependent upon the exercise of state authority.

A contingent theory of aboriginal right gives rise to a particular conception of the meaning of First Nations sovereignty and self-government. Under a contingent rights approach, First Nations sovereignty would not exist as a constitutional right until expressed by way of constitutional amendment. Until such a time, aboriginal selfgovernment exists only to the extent it is given force by legislation or executive action. For example, the agreement between the Sechelt Indian Band, British Columbia, and the Federal government authorizing the Sechelt Band to contract and hold property, and exercise jurisdiction over education, health and social and welfare services, ${ }^{19}$ is imagined in law as having legal force and effect as a result of the passage of implementing legislation conferring such powers upon the Sechelt Band. ${ }^{20}$ Thus, under a contingent theory of aboriginal right, self-government is a label for a bundle of rights that attach to Native people as a result of legislative or executive action or constitutional amendment, and is not dependent upon a prior acceptance of First Nations sovereignty. In fact, a contingent theory of aboriginal right implicitly denies any assertion of First Nations sovereignty by viewing the existence or non-existence of aboriginal rights, including rights of self-government, as dependent upon the exercise of Canadian sovereign authority.

Justice Hall in Calder did more than criticize Davey C.J.B.C.'s characterization of the aboriginal rights of the Nishga Nation, for he also wrote that "aboriginal Indian title does not depend on treaty, executive order or legislative enactment."21 In so holding, Justice Hall articulated an inherent theory of aboriginal right, which views aboriginal rights as existing independently of any legislative or executive action. According to an inherent rights perspective, aboriginal rights inhere in the very meaning of aboriginality. The production and reproduction of native forms of community require a system of rights and obligations that reflect and protect unique relations that native people have with nature, themselves and other communities. ${ }^{22}$ Being inherent, such rights do not depend on executive or legislative conferral for their existence, though their reception and therefore

17. R.S.M. 1970, c. N30, para. 13.

18. Ibid.

19. See Cassidy and Bish, Indian Government: Its Meaning in Practice (Lantzville: Oolichan, 1989).

20. See Sechelt Indian Band Self-Government Act, S.C. 1986, c. 27.

21. Supra, note 15 at 200.

22. See, for one aspect, M. Boldt \& J.A. Long, "Tribal Philosophies and the Canadian Charter of Rights and Freedoms" in Boldt \& Long, eds, The Quest For Justice: Aboriginal Peoples and Aboriginal Rights (Toronto: University of Toronto Press, 1985) 165 at 169 (aboriginal conceptions of right are group-based and defined "in terms of the common interest"). 
enforcement in Canadian law is at least dependent upon judicial recognition of their existence.

An inherent theory of aboriginal right generates an approach to First Nations sovereignty and self-government that stands in stark contrast to that envisioned by a contingent rights perspective. According to an inherent rights approach, First Nations sovereignty is a term used to describe the totality of powers and responsibilities necessary or integral to the maintenance and reproduction of aboriginal identity and social organization. Under an inherent rights theory, First Nations sovereignty and aboriginal forms of government, as the means by which aboriginal identity and social organization are reproduced, pre-existed the settlement of Canada and continue to exist notwithstanding the interposition of the Canadian state. The Canadian state may choose to recognize aspects of First Nations sovereignty and aboriginal forms of self-government through executive, legislative or judicial action. Unlike a contingent theory of aboriginal right, however, such action is not necessary for the existence of First Nations sovereignty and native forms of self-government, only their recognition in Canadian law.

The debate between Justice Hall and Chief Justice Davey as to the legal nature of aboriginal rights was initially put to rest in 1984 by Dickson J. (as he then was) in Guerin v. The Queen. ${ }^{23}$ Describing the nature of the Musqueam Indian Band's interest in their land as "a pre-existing legal right not created by Royal Proclamation, by s. 18(1) of the Indian Act, or by any other executive order or legislative provision," ${ }^{24}$ Dickson $\mathrm{J}$. in Guerin firmly opted for an inherent theory of aboriginal right. Yet, prior to the passage of the Constitution Act, 1982, the legal embrace of an inherent theory of aboriginal right was restricted to the common law. Although aboriginal rights in Guerin were conceived as not contingent upon the exercise of legislative or executive authority, they nonetheless existed only at common law. Common law aboriginal rights were therefore always subject to regulation or extinguishment by the appropriate legislative authority. ${ }^{25}$ The judicial recognition of the inherent nature of aboriginal rights thus occurred in the context of a tacit acceptance of the sovereign authority of the Canadian state over its indigenous population. As a result, the vision of First Nations sovereignty and native forms of selfgovernment generated by an inherent theory of aboriginal right remained outside the purview of Canadian law.

\section{THE SPARROW DECISION}

The passage of the Constitution Act, 1982 creates a new context for the re-emergence of the debate between a contingent theory and an inherent theory of aboriginal right. Three provisions are relevant. The first is $\mathrm{s} .25$, which provides:

23. Supra, note 1 .

24. Ibid. at 336.

25. Supra, note 15, quoting Lipan Apache v. United States, 180 U.S. Ct. Cl. 487 (1967), Hall J. argued that any legislative extinguishment must be "clear and plain". This was subsequently affirmed by Dickson C.J. and La Forest J. in R. v. Sparrow, supra, note 5. 
The guarantee in this Charter of certain rights and freedoms shall not be construed so as to abrogate or derogate from any aboriginal, treaty or other rights or freedoms that pertain to the aboriginal peoples of Canada including

(a) any rights or freedoms that have been recognized by the Royal Proclamation of October 7, 1963; and

(b) any rights or freedoms that now exist by way of land claims agreements or may be so acquired. ${ }^{26}$

Section 25 , in other words, shields aboriginal rights from potential judicial holdings that their exercise constitutes violations of individual or collective rights and freedoms enshrined in the Canadian Charter of Rights and Freedoms.

The second relevant provision is s. 35 . Section $35(2)$ defines the "aboriginal peoples of Canada" as including "the Indian, Inuit and Metis peoples of Canada,"27 a clause that is of particular importance to the Metis who previously were in an ambiguous legal position regarding their status as aboriginal peoples. ${ }^{28}$ Section 35(3) ensures among other matters that rights obtained through the settlement of contemporary land claims are to be considered as constitutionally equivalent to treaty rights and therefore constitutionally protected under the Constitution Act, 1982. Finally, and most importantly, s. 35(1) provides that "[t]he existing aboriginal and treaty rights of the aboriginal peoples of Canada are hereby recognized and affirmed."29

The third provision of the Constitution Act, 1982 of note is s. 37. The Constitution Act, 1982 did not specify the scope and content of the "aboriginal and treaty rights" that it recognized and affirmed. This was to be done, at least in part, through a series of conferences to be held pursuant to s. 37.1. According to s. 37.1(2), each of these conferences was to "have included in its agenda constitutional matters that directly affect the aboriginal peoples of Canada. ${ }^{30}$ The original version of the Constitution Act, 1982 went on to state explicitly that the agenda was to include "the identification and definition of the rights of those peoples to be included in the Constitution of Canada." ${ }^{.11}$ However, this clause was dropped from versions subsequent to April 17, 1983. Nonetheless, it is clear from the constitutional discussions that took place under s. 37 that their primary purpose was to identify and define aboriginal and treaty rights. This series of conferences ended in 1987, with no agreement among governments and aboriginal representatives on the identification and definition of aboriginal and treaty rights. Thus, despite textual recognition and affirmation of existing aboriginal rights, the Canadian Constitution remains silent on their specific scope and content.

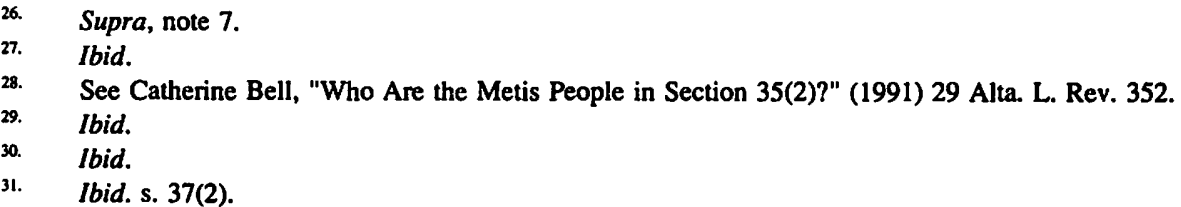


In $R$. v. Sparrow, however, the Supreme Court of Canada was provided with the occasion to give meaning to s. 35(1). As stated previously, the Court accepted that Canada enjoys sovereignty and is therefore entitled to exercise legislative authority over First Nations. The Court held, however, that aboriginal rights that exist at common law are now "recognized and affirmed" by s. 35(1), and that, as a result, laws that interfere with the exercise of such rights must conform to constitutional standards of justification. More specifically, the Court held that, upon a showing of an infringement of a s. 35(1) right, the government must at least demonstrate a valid legislative objective, and any allocation of priorities after such objective has been implemented must give "priority" to aboriginal interests. ${ }^{32}$ It also stated that in future cases it may require adequate consultation with aboriginal peoples as a precondition of the constitutionality of laws that infringe s. $35(1)$ rights. ${ }^{33}$

In so holding, the Court re-affirmed Dickson J.'s holding in Guerin that aboriginal rights are not contingent upon the exercise of legislative or executive authority, and to this extent the Court in Sparrow embraced an inherent theory of aboriginal right. In the Court's view, the reason for concluding that the Musqueam Nation enjoys a right to fish lies not in the presence of state action conferring such a right, but instead arises from the fact that fishing is integral to Musqueam self-identity and self-preservation. More specifically, the Court stated the following:

The evidence reveals that the Musqueam have lived in the area as an organized society long before the coming of European settlers, and that the taking of salmon was an integral part of their lives and remains so to this day. ${ }^{34}$

Elsewhere in their reasons, Dickson C.J. and La Forest J. make a similar point:

The anthropological evidence relied on to establish the existence of the right suggests that, for the Musqueam, the salmon fishery has always constituted an integral part of their distinctive culture. Its significant role involved not only consumption for subsistence purposes, but also consumption of salmon on ceremonial and social occasions. The Musqueam have always fished for reasons connected with their cultural and physical survival. ${ }^{35}$

Supra, note 5 at 416 . The Court ordered a retrial to determine whether the net length restriction in fact infringed the Musqueam right to fish and, if so, whether such infringement met the aforementioned constitutional standard of justification.

Ibid. at 416-17. In the words of Dickson C.J. and La Forest J.:

"[t]he aboriginal peoples, with their history of conservationconsciousness and interdependence with natural resources, would surely be expected, at the least, to be informed regarding the determination of an appropriate scheme for the regulation of the fisheries."

34. Ibid. at 398.

35. Ibid, at 402 . 
Fishing, in other words, ought to viewed as an aboriginal right because it formed and continues to form an "integral part" of Musqueam life. The content of aboriginal rights thus is to be determined not by reference to whether executive or legislative action conferred such a right on the people in question, but rather by reference to that which is essential to or inheres in the unique relations that native people have with nature, each other, and other communities.

The Court's interpretation of the nature of the rights recognized and affirmed by s. 35(1) is of crucial importance to the constitutional protection of aboriginal forms of selfgovernment. More specifically, by its embrace of an inherent theory of aboriginal right, the Court cautiously opens the door for constitutional recognition of an aboriginal right to self-government. In contrast to a contingent rights approach, the embrace of an inherent theory of aboriginal right in the context of s. 35(1) entails that s. 35(1) recognizes and affirms that which is essential to or inheres in the unique relations Native people have with nature and each other. Such practices or forms of social organization do not require the imprimatur of state action to qualify as rights. Constitutional recognition of an aboriginal right to self-government could thus occur in the following way. The right to fish was viewed by the Court as a right because of its centrality to Musqueam culture. If fishing is central to the Musqueam Nation, the ability to determine how this activity will be carried out on Musqueam lands, between the Musqueam and others, and among the Musqueam themselves must also be central to its self-definition. ${ }^{36}$ That is, the ability to pass laws or rules governing how the practice of fishing is to occur, under the theory of aboriginal right adopted by the Court in Sparrow, equally ought to qualify as an aboriginal right under s. 35(1). Whether s. 35(1) recognizes and affirms such a right will depend on the meaning given to the further requirement that such a right be "existing."

It is when one moves from forms of self-government to aboriginal sovereignty that the implications of embracing an inherent theory of aboriginal right emerge with some clarity. As stated in Part I of this essay, aboriginal sovereignty, under an inherent rights approach, refers to the totality of powers and responsibilities necessary to maintain and reproduce aboriginal identity and aboriginal social organization, whereas forms of self-government are a crucial means by which aboriginal identity and social organization are maintained and reproduced. The ability to determine how fishing is to occur, for example, is a form of aboriginal self-government, yet there may be many other forms of self-governance that speak to other aspects of aboriginal identity and social organization. Such forms of selfgovernment represent the means by which a specific culture reproduces its own distinct identity. Aboriginal sovereignty can be viewed as a term that refers to the totality of powers necessary or integral to the reproduction of aboriginal identity. Given that an inherent theory of aboriginal right accords the status of right to essential or integral

Compare Mahe v. The Queen (1990), 68 D.L.R. (4th) 69 (S.C.C.) where the court, per Dickson C.J., held that s. 23 of the Canadian Charter of Rights and Freedoms, which grants minority language educational rights to minority language parents throughout Canada, encompasses a right to management and control of the facilities in question. 
components of aboriginal identity, aboriginal sovereignty ought to qualify as an aboriginal right under the theory of right embraced by the Court in Sparrow.

The Court avoided some of the above implications of adopting an inherent theory of aboriginal right by making two critical moves. First, the Court unquestioningly accepted that the British Crown, and thereafter Canada, obtained territorial sovereignty over the land mass that is now Canada by the mere fact of European settlement. The Court's acceptance of the settlement thesis appears to exclude any possibility of the recognition and affirmation of a constitutional right to aboriginal sovereignty. Second, the embrace of the settlement thesis permitted the Court to rein in the scope of s. 35(1) by relying on a contingent rights approach to s. 35(1)'s requirement that aboriginal rights be "existing". The definition of "existing" offered by the Court weakens and renders fragile the constitutional protection of aboriginal forms of self-government that would otherwise flow from an inherent theory of aboriginal right.

With respect to the assertion of Canadian sovereignty, the Court made the following crucial statement:

It is worth recalling that while British policy toward the native population was based on respect for their right to occupy their traditional lands, a proposition to which the Royal Proclamation of 1763 bears witness, there was from the outset never any doubt that sovereignty and legislative power, and indeed the underlying title, to such lands vested in the Crown. ${ }^{37}$

With this statement, the Court has indicated that it is of the view that, whatever the meaning given to s. 35(1), Canadian sovereignty over the indigenous population that finds itself within Canada is unquestioned. If Canadian sovereignty was "never in doubt," its assertion likely had the effect of subsuming pre-existing aboriginal sovereignty to the overarching authority of the Canadian state. Thus, unlike other aboriginal rights, the Court appears to accept the proposition that the right to sovereignty, however acceptable under an inherent theory of aboriginal right, is to be excluded a priori from the scope of s. 35(1). It is important to note that underlying this interpretation of $s .35(1)$ is a contingent theory of aboriginal right, which views the existence of an aboriginal right, in this case a right to aboriginal sovereignty, as dependent upon legislative or executive action. Since the Canadian state decided not to respect aboriginal sovereignty, such sovereignty cannot achieve the status of right.

The Court also implicitly relies on a contingent theory of aboriginal right in the definition it gives s. 35(1)'s requirement that aboriginal rights be "existing" before they receive constitutional recognition and affirmation. An inherent theory of aboriginal right would suggest that the existence of aboriginal rights is not to be determined by reference to actions of the Canadian state. The Court, however, held that prior to 1982 aboriginal rights could be extinguished by the Canadian state. If extinguished prior to 1982, 
aboriginal rights no longer "exist" within the meaning of s. 35(1) and their exercise is not protected against state action. If such rights were only regulated, they continue to exist within the meaning of s. 35(1) despite their regulation and can serve to check subsequent legislative or executive curtailment. State action, in other words, defines the parameters of s. 35(1) rights, which is a central tenet of a contingent theory of aboriginal right.

The definition of "existing" offered by the Court makes for but a fragile embrace of a constitutional right of aboriginal self-government. To extend the fishing example further, pre-1982 federal laws respecting fishing by the Musqueam Nation may well have regulated the Musqueam's ability to determine among themselves how, when and by whom fishing is to occur. Whether this form of self-government by the Musqueam Nation continues to exist and, therefore, is recognized and affirmed by s. 35(1) is dependent upon a finding that the practice was not extinguished by law prior to 1982 . The assertion of Canadian sovereignty alone would not have extinguished the right of Musqueam to determine among themselves how fishing is to occur; it would be necessary to further determine whether legislative power that flowed from the assertion of sovereignty has in fact been exercised in such a way as to extinguish the right in question. Such a determination, in our view, would be fact-specific and may well vary from case to case. As such, the commitment to a right to aboriginal self-government in Sparrow, initiated by the adoption of an inherent theory of aboriginal right, is ultimately rendered fragile and tentative by the Court's subsequent embrace of the competing contingent rights approach and the Court's unquestioned acceptance of Canadian sovereignty.

In sum, although the Court in Sparrow pays attention to an inherent theory of aboriginal right, its reasons ultimately betray a reliance on a contingent rights perspective, which serves to rein in the scope of s. 35(1) rights. The assertion of Canadian sovereignty is sufficient to nullify and render non-existent any pre-existing claims of aboriginal sovereignty, which would otherwise constitute an "existing aboriginal right" within the meaning of s. 35(1). Whether native forms of government continue to exist within the meaning of s. 35 in turn depends on the presence of legislative action. Because this interpretation of s. 35(1) will have profound implications for the ability of First Nations to shield their forms of life from state interference in the future, it is necessary to explore further the assumptions underlying a contingent theory of aboriginal right and the Court's acceptance of Canadian sovereignty.

\section{SOVEREIGNTY AND THE SETTLEMENT THESIS}

The view that "sovereignty and legislative power ... vested in the Crown", ${ }^{38}$ an assumption that informed the Court's preliminary reading of the scope of s. 35(1) rights in $R$. v. Sparrow, is not a new idea in Canadian constitutional thought. It also informs judicial and political understandings of the meaning of the Constitution Act, 1867. The Constitution Act, 1867 is perhaps Canada's most fundamental constitutional document 
with respect to the assertion of political dominion over the landmass now called Canada and the distribution of legislative power between the two levels of government in the Canadian political system.

As is common knowledge, the Constitution Act, 1867 indicates that the Canadian state is to be federal in nature with two levels of government, and lists a range of subjectmatters in ss. 91 and 92 in relation to which each level of government is authorized to exercise legislative authority. Section 91 describes in both general and specific terms the areas of legislative authority enjoyed by Parliament, and includes, among other items, the right to pass laws in relation to the regulation of trade and commerce (s. 91(2)), taxation (s. 91(3)), and criminal law (s. 91(27)). Sections 92 and 93 list subject-matters over which provincial legislatures are entitled to exercise jurisdiction, such as "the management and Sale of Public Lands belonging to the Province" (s. 92(5)), property and civil rights in the province (s. 92(13)), and education (s. 93)). The preamble to the Constitution Act, 1867 makes it clear that the constitution of Canada was undertaken as an act of federal union by specific provinces in British North America. It suggests that the previous provincial authorities united for the purpose of constructing a "Constitution similar in principle to that of the United Kingdom." ${ }^{13}$ The Constitution Act, 1867 can be said to be an ahistorical document, in that it makes no mention of earlier conditions out of which the union emerged.

Aboriginal peoples are referred to only once in the Constitution Act, 1867, in s. 91(24). Section 91(24) provides that "the exclusive Legislative Authority of the Parliament of Canada extends to ... Indians, and Lands reserved for the Indians. ${ }^{140}$ In other words, the Constitution Act, 1867 specifies that Indians and lands reserved for Indians fall under the exclusive legislative authority of Parliament. Section 91(24) has been uniformly thought by legislators and the judiciary to assert unilateral dominion over Indians and lands reserved for Indians, an interpretation that conforms with the Constitution Act's ahistorical division of all legislative sovereignty within the dominion into either the federal or provincial sphere. Thus, s. 91(24) may be initially pointed to as justification for the view articulated by Dickson C.J. and La Forest J. in Sparrow that "sovereignty and legislative power [as against the aboriginal population] ... vested in the Crown." ${ }^{41}$ The Constitution Act, 1867 clearly specifies that Parliament enjoys exclusive legislative power with respect to Indians and lands reserved for Indians; read this way, it provides strong support for concluding that aboriginal sovereignty no longer exists in Canada, a conclusion which in turn supports the invocation of a contingent theory of aboriginal right in the context of s. 35(1) of the Constitution Act, 1982.

In negotiations with First Nations concerning aboriginal self-government, governments have remained faithful to this interpretation of s. 91(24) and the proposition that Canadian sovereignty extinguished aboriginal sovereignty. For example, in the First Ministers'

39. $\quad$ Ibid.
40.
41. $\quad$ Supra, note 5.


Conferences on aboriginal affairs in the 1980s, successive Canadian governments maintained that recognition of legislative authority of aboriginal governments would require explicit constitutional amendment. ${ }^{42}$ The federal government refused to interpret s. 91(24) as providing an opportunity to assert such recognition, thereby bypassing the current amending formula which requires the consent of seven provinces presenting at least $50 \%$ of the population. ${ }^{43}$ Moreover, with the recent exception of Ontario, governments have insisted that any self-government agreements with First Nations be based either on the principle of "delegated authority" (or a form that expressly acknowledges the sovereignty of the provinces and the federal government), or through a form of "legislative authority," as in the case of the Sechelt Indian Band, ${ }^{44}$ which can be unilaterally altered or withdrawn by Parliament. This position conforms with the contingent rights thesis that aboriginal sovereignty was extinguished by the assertion of territorial sovereignty by the Crown and subsequently Canada. First Nations selfgovernment is imagined as a policy option, as constituting a bundle of rights that attach to native people as a result of legislative or executive action.

Yet nowhere in the Constitution Act, 1867 does it actually state that the Canadian state enjoys sovereignty over its indigenous population. The assumption that the Canadian state does enjoy sovereignty over its indigenous population justifies, but is not justified by, interpreting s. 91(24) as authorizing Parliament to pass laws governing its indigenous population absent consent of that population. If one removes the underlying assumption of Canadian sovereignty over native people from the interpretive picture, s. 91(24) could just as easily be read as not authorizing Parliament to pass laws in relation to native people absent their consent, but simply providing that, as between Parliament and provincial legislatures, Parliament has the exclusive authority to negotiate with Canada's indigenous population and to regulate Indian affairs if and when negotiations have resulted in treaties of mutual consent. Thus, despite initial appearances to the contrary, the justification for the assertion of Canadian sovereignty, an assertion which underpins the coherence of the contingent theory of aboriginal right, cannot to be located in the text of the Constitution Act, 1867.

In our view, the assertion of Canadian sovereignty over aboriginal peoples, as well as the contingent theory of aboriginal right that it generates, ultimately rest on unacceptable notions about the inherent superiority of European nations. If this is true, unquestioned acceptance of Canadian sovereignty and a contingent theory of aboriginal right does violence to fundamental principles of justice and human rights in the modern world, such as the assumed equality of peoples, especially of their ability to govern themselves, and the basic right of a people to self-determination. We believe it abhorrent that Canada was constituted in part by reliance on a belief in inequality of peoples and that such a belief continues to inform political and legal practice in 1991.

\footnotetext{
42 For more discussion, see Asch, "Aboriginal Self-Government and the Construction of Canadian Constitutional Identity" supra, note 9.

43. Supra, note 7, s. 38.

4. See text accompanying notes 18-19, supra.
} 
That Canada was indeed constituted in part by a belief in the inequality of peoples is borne out by an examination of the justifications relied on by Great Britain and later adopted by Canada to assert its right to territorial sovereignty. As outlined by Brian Slattery, there are four principles of law upon which states have traditionally relied to justify the acquisition of new territory. These are: (1) conquest or the military subjugation of a territory over which the conqueror clearly expresses a desire to assume sovereignty on a permanent basis; (2) cession or the formal transfer of a territory from one independent political unit to another; (3) annexation or the assertion of sovereignty over another political entity without military action or treaty; and (4) the settlement or acquisition of territory that was previously unoccupied or is not recognized as belonging to another political entity. ${ }^{45}$

It is not difficult to imagine the use of all of these arguments in defence of Canada's claim to sovereignty over its territory. In our view, however, the Court in Sparrow was implicitly relying on a version of the settlement thesis. The settlement thesis, of course, is reasonable in cases where the land over which sovereignty is asserted was unoccupied prior to settlement. The difficulty arises in cases where it is used as a justification for the assertion of territorial sovereignty over prior occupants. A commonly accepted justification for the assertion of sovereignty by settlement in such circumstances is the view that the settlers were superior to the original inhabitants, especially with respect to a characteristic akin to political organization; in short, that, in contrast to the settlers, the original inhabitants were either too primitive to possess "sovereignty" or, at the least, possessed it in such a rudimentary form that its existence did not deserve to be respected by the more "advanced" settler society ${ }^{46}$ Thus territorial sovereignty, when examined in light of the competing claims of the settlers and the original inhabitants, more appropriately vests in the former. This justification surfaced with colonial expansion and included such particulars as the superiority of Christianity over heathen religions, of agriculture over hunting and gathering, of western cultural institutions such as private property over non-western notions, and, of course, of one skin colour over another. ${ }^{47}$

It is precisely this version of the settlement thesis that lies behind the view that aboriginal sovereignty was extinguished by the assertion of sovereignty by the Crown. No other interpretive frame used to justify the acquisition of new, populated territories by a sovereign can make sense of the position that aboriginal sovereignty was extinguished

45. B. Slattery, The Land Rights of Indigenous Canadian Peoples, as Affected by the Crown's Acquisition of Their Territories (D. Phil. Thesis, Oxford University, 1979 reprinted Saskatoon: University of Saskatchewan Native Law Centre, 1979).

46. See, generally, J. Crawford, The Creation of States in International Law (Oxford: Oxford University Press, 1979) at 176-81.

47. See, generally, R.A. Williams, Jr., The American Indian in Western Legal Thought: The Discourses of Conquest (New York: Oxford University Press, 1990); and M. Asch, Home and Native Land: Aboriginal Rights and the Canadian Constitution (Toronto: Methuen, 1984) at 22-25, 42-46; and S. Lester Geoffrey, "Primitivism v. Civilization: A Basic Question in the Law of Aboriginal Rights to Land" in C. Brice-Bennett, ed., Our Footprints Are Everywhere (Nfld: Labrador Inuit Association, 1977) at 351. 
by the assertion of Crown sovereignty. ${ }^{48}$ It grounds the dominant understanding of $s$. 91(24) as conferring legislative power on Parliament to pass laws governing native people absent their consent. The absence of aboriginal sovereignty permits viewing s. 91(24) as conferring legislative authority over native peoples absent their consent on Parliament. ${ }^{49}$ It explains why "there was from the outset never any doubt that sovereignty and legislative power ... vested in the Crown." The reason for certainty lay in perceived European superiority. And it renders coherent the contingent theory of aboriginal rights to sovereignty and self-government, which views the existence of aboriginal rights as dependent upon Canadian executive or legislative action. Sovereignty is viewed as an erroneous label for a bundle of rights dependent for their existence on the sovereign authority of the Canadian state, and the constitutional recognition of aboriginal forms of self-government is contingent upon their non-extinguishment by legislative or executive action prior to 1982 .

Thus a belief in the inherent superiority of European nations ultimately supports the unquestioned acceptance of Canadian sovereignty and the invocation of a contingent rights approach to the term "existing" in s. 35(1) of the Constitution Act, 1982 by the Court in Sparrow. This is not to suggest that the Court actually subscribes to this view; the tenor of the judgment strongly suggests the opposite. It is to claim, however, that the Court's reasons for moving away from an inherent theory of aboriginal right in the manner described previously can only be supported by a belief in the inherent superiority of European nations. In our view, such a position is unacceptable as a constituting principle of Canada's identity and ought to be removed from the stock of interpretive tenets brought to bear by the judiciary when giving meaning to the Constitution of Canada. In its place, we suggest that s. 35(1) of the Constitution Act, 1982 be interpreted by reference to the overarching value of equality of peoples. Such a value entails the constitutional embrace of an inherent theory of aboriginal right. In the alternative, we suggest that the judiciary deepen Sparrow's tentative commitment to an aboriginal right of self-government.

\section{TWO ALTERNATIVES}

One alternative to the Court's approach in Sparrow would be to banish the settlement thesis from constitutional reasoning. The removal of the settlement thesis from the fabric of constitutional discourse would not eliminate other potential justifications for the assertion of Canadian sovereignty. Cession theoretically could serve as a yardstick for determining whether aboriginal sovereignty and forms of self-government continue to exist within the meaning of s. 35(1). Canada could point to the existence of numerous treaties, such as the numbered treaties applicable to the plains. ${ }^{50}$ Of particular importance is the clause, found in all post-Confederation treaties that provides that "(the said) Indians ...

48. For more discussion, see Asch, supra, note 9.

49. For more discussion, see Macklem, supra, note 9.

so. The texts of the numbered treaties are available in A. Morris, The Treaties of Canada With the Indians of Manitoba and the North-West Territories (1980: reprint ed., Toronto: Coles Publishing, 1971). 
cede, release, surrender and yield up to the Government of the Dominion of Canada, for Her Majesty the Queen, and Her successors forever, all their rights, titles and privileges whatsoever, to the lands included ..." ${ }^{51}$ It is not difficult to imagine a court challenge on sovereignty being met with the claim that sovereignty was transferred by cession. Unlike sovereignty by settlement in the context of populated land, sovereignty by cession is not a principle necessarily undeserving of constitutional embrace; based on the will of parties, it suggests that the transfer of sovereignty ought to be a matter of agreement and not simply brute force.

If the aforementioned treaties were, in fact, formal cessions of sovereignty, sovereignty by cession might be deserving of constitutional stature, at least with respect to those regions covered by treaty. ${ }^{52}$ In fact, however, it is questionable whether treaties entered into by the Crown with native people represent formal cessions, based on the "free will" of aboriginal nations, that cede unilateral sovereignty to the Crown. That is, are the written versions of the treaties accurate descriptions of the agreements reached by the relevant parties? There are strong doubts. First, aboriginal nations from all over Canada argue that the written versions in fact are not accurate. In their view, treaties were produced in the spirit of "peace and friendship" to allow for peaceful settlement of nonnatives on aboriginal lands, potentially to form a political relationship between two sovereigns, perhaps even a shared form of sovereignty akin to a confederation, ${ }^{53}$ but were never considered to provide for unilateral cessions of sovereignty. Second, Crown negotiators were operating under the assumption that the Crown already possessed sovereignty over Canada's indigenous population and that Parliament was entitled to pass laws governing native people absent their consent by virtue of s. 91(24) of the

\section{st. Ibid.}

52. It should be noted that the clause accompanying note 49 makes no reference to sovereignty and reasonably could be construed to refer only to land rights.

53. For an illustration of the concept of shared sovereignty, see Treaty With the Delawares, 1778, entered into by the United States of America and the Delaware Nation, and reproduced in C.J. Kappler, ed., Laws and Treaties, vol. 2, Treaties (Washington: Government Printing, 1904). Article II, for example, provides:

"That a perpetual peace and friendship shall from henceforth take place, and subsist between the contracting parties aforesaid, through all succeeding generations: and if either of the parties are engaged in a just and necessary war with any other nation or nations, that then each shall assist the other in due proportion to their abilities, till their enemies are brought to reasonable terms of accommodation: and that if either of them shall discover any hostile designs forming against the other, they shall give the earliest notice thereof, that timely measures may be taken to prevent their ill effect."

Similarly, Article VI provides:

"And it is further agreed on between the contracting parties should it for the future be found conclusive for the mutual interest of both parties to invite any other tribes who have been friends to the interest of the United States, to join the present confederation, and to form a state whereof the Delaware nation shall be the head, and have a representation in Congress: Provided, nothing contained in this article is to be considered as conclusive until it meets with the approbation of Congress." 
Constitution Act, 1867. To speak of a meeting of the minds on the question of a formal transfer of sovereignty in this context is thus highly problematic.

If cession, unlike settlement, was viewed as a legitimate means by which Canada could assert sovereignty over its indigenous population, Canada would be required to negotiate treaties with the relevant indigenous population before it could legitimately assert sovereignty over that population. Moreover, it would have to be demonstrated that treaties actually represent formal transfers of sovereignty before Parliament could pass laws governing native people absent their consent pursuant to s. 91(24) of the Constitution Act, 1867. Finally, in the absence of a formal transfer of sovereignty through cession, Canada would have to recognize the continued existence of aboriginal sovereignty and respect preexisting native forms of self-government. In other words, an inherent theory of aboriginal right would provide a constitutional lens of mutual understanding with respect to Canada's relations with the First Nations of North America.

The constitutional embrace of an inherent theory of aboriginal right would generate an alternative understanding of the role of s. 91(24) of the Constitution Act, 1867 in the structure of Canadian federalism. To reiterate, instead of viewing s. 91(24) as an expression of the sovereign authority of Canada over its indigenous population and the allocation of legislative jurisdiction to Parliament, it would be viewed as providing that, as between the provincial legislatures and Parliament, Parliament has the exclusive authority to negotiate with First Nations and to legislate with respect to Indian affairs if and when negotiations have resulted in treaties of mutual consent. ${ }^{54}$

The rejection of the settlement thesis and the invocation of an inherent theory of aboriginal right would also spawn an alternative understanding of s. 35(1) of the Constitution Act, 1982. Aboriginal sovereignty and native forms of self-government, essential as they are to the establishment, maintenance, and reproduction of aboriginal identity, would acquire the status of a right. A rejection of the settlement thesis would permit the conclusion that aboriginal sovereignty and forms of self-government continue to exist within the meaning of, and therefore are "recognized and affirmed" by, s. 35(1), at least in cases where they were not expressly extinguished by true acts of cession. Section 35(1) would become the means whereby aboriginal forms of life are protected from legislative or executive intervention by requiring the state to justify the assertion of sovereignty underpinning the intervention in question. ${ }^{55}$ Aboriginal sovereignty and native self-government would therefore be elevated to the level of constitutional right, with the important exception that, unlike rights guaranteed by the Charter, s. 35(1) rights to sovereignty and aboriginal self-government would not be subject to demonstrably justifiable limitations. Laws that infringe on aboriginal sovereignty and thereby exceed

For an analysis of the implications of this approach with respect to provincial jurisdiction, see B. Ryder, "The Demise and Rise of the Classical Paradigm in Canadian Federalism: Promoting Autonomy for the Provinces and First Nations" (1991) McGill L.J. (forthcoming). 
the sovereign authority of Canada could not be viewed as constitutionally acceptable exercises of state power.

We understand that the above interpretation initially may not be palatable to a legal imagination that views the world through a particular set of evolutionary lenses. An alternative to challenging the settlement thesis at present would be to deepen the tentative commitment in Sparrow to the constitutional protection of aboriginal forms of selfgovernment. That is, Sparrow does provide an albeit fragile foundation for the constitutional recognition of aboriginal forms of self-government by its partial embrace of an inherent theory of aboriginal right. Some of the damage caused by the unquestioned acceptance of the settlement thesis could be offset by an explicit holding that $s .35(1)$ recognizes and affirms an aboriginal right to self-government. According to the framework laid down by the Court in Sparrow, it would have to be demonstrated that such a right was not extinguished by state action prior to 1982, and its existence would not preclude legislative infringements so long as such infringements met the standards of justification articulated by the Court. Yet these requirements could be interpreted in subsequent cases to provide for deeper protection of forms of aboriginal self-government. The test for determining whether forms of self-government were extinguished prior to 1982 could be set strictly. Equally, the standards for determining whether laws that infringe on a recognized right of self-government are nonetheless justifiable could be strengthened, perhaps by building on the intimation in Sparrow that native participation in the formation of laws that affect native interests is a precondition of constitutionality. ${ }^{56}$

Despite the attractiveness of this second alternative, we believe it merely delays engaging in the necessary task of shifting Canada's constitutional identity toward a thesis that accepts the premise of the equality of peoples. In calling for this shift, we are drawn to the following statement by Justice Hall in the Calder case written more than twenty years ago:

\footnotetext{
[t]he assessment and interpretation of the historical documents and enactments tendered in evidence must be approached in the light of present-day research and knowledge disregarding ancient concepts formulated when understanding of the customs and culture of our original people was rudimentary and incomplete and when they were thought to be wholly without cohesion, laws or culture, in effect a subhuman species. ${ }^{57}$
}

Justice Hall was aiming this well-phrased barb at Chief Justice Davey's remarks, quoted in Part I of this essay, that the Nishga Nation was a "very primitive people with few of the institutions of civilized society." 58 In our view, it is equally applicable to the invocation of a contingent theory of aboriginal right in the context of s. 35(1) of the Constitution Act, 1982. The stability of a contingent rights approach to s. 35(1) ultimately

Supra, note 13.
} 
depends on a belief in the superiority of European nations. In our view, Canada ought not to be constituted by a reliance on such a belief, and constitutional interpretation surrounding Canada's relation with First Nations should heed Justice Hall's sage advice. An inherent theory of aboriginal right remains true to the belief of equality of peoples and as such should form an integral part of Canada's constitutional identity.

\section{CONCLUSION}

Canada clearly is at a pivotal moment in its constitutional history. Elijah Harper's dramatic stance in the Manitoba legislature in the summer of 1990 derailed a constitutional train of events that was already dangerously out of control. The ensuing wreckage - bitter denunciations and personal attacks by leading politicians, rudderless federal authority, the establishment of travelling group therapy inquiries, and the resurrection of the independence option - is traumatic, disorienting, and offers little in the way of survivors. Yet, trauma often permits the exploration of previously unexplored assumptions about the values by which we live our lives and, as a result, the possibility of growth and transformation.

There are profound legal lessons to be learned from the powerful symbolism of Elijah Harper's actions, lessons that cut to the core of fundamental assumptions about the constitution of Canada. While they have little to do with Quebec's renewed aspiration for independence, these lessons do bear directly upon the future place of First Nations in a new Canadian confederation and even in an independent Quebec. More specifically, the import of Elijah Harper's actions lies in the fact that they represent a reaction against a deep-rooted process of constitutional exclusion of First Nations in the definition of Canada. It is this process of constitutional exclusion, namely, its source and entrenchment, that this essay has attempted to explicate. Our hope is that this exploration of the historical assumptions that have promoted the exclusion of First Nations from constitutional discourse will ultimately serve what we believe to be a laudable goal of inclusion in a new constitutional order.

Whatever its ultimate configuration, a new constitutional order must address First Nations' claims of an aboriginal right to sovereignty and self-government. In this essay, we have attempted to articulate the basic elements of two competing theories of aboriginal right. The first, a contingent rights approach, which requires state action for the existence of aboriginal rights, dominated early judicial pronouncements on the nature of aboriginal rights. The second, an inherent rights approach, which views aboriginal rights as inherent in the nature of aboriginality, came to be embraced by the judiciary in cases addressing the nature of aboriginal legal interests prior to the passage of the Constitution Act, 1982 . In $R$. v. Sparrow, and despite other laudable aspects of the judgment, the Court addressed the meaning of 35(1) of the Constitution Act, 1982 and ultimately betrayed a reliance upon a contingent theory of aboriginal right. As a result, the Court severely curtailed the possibility that s. $35(1)$ includes an aboriginal right to sovereignty and rendered fragile $s$. $35(1)$ 's embrace of a constitutional right to self-government. 
In our view, the re-emergence of a contingent theory of aboriginal right in the context of s. 35(1) jurisprudence ultimately depends on a belief in the superiority of European nations, and is therefore antithetical to principles that ought to underpin Canada's constitutional self-definition. In its place, we suggest the embrace of an inherent theory of aboriginal right, which would protect aboriginal sovereignty and native forms of selfgovernment from state interference. Such an approach would begin to reverse the historical pattern of systematic exclusion of Canada's First Nations from constitutional discourse and acknowledge the importance of native difference in the constitution of Canada. In the alternative, we suggest that the judiciary attempt to shore up the tentative acceptance of a constitutional right to self-government.

We believe there is more merit in confronting the settlement thesis directly. We well recognize that such an approach generates its own fears, not the least of which is the concern that a recognition of an inherent right of aboriginal sovereignty might lead to a constitutional hiatus. We understand this fear, and do not welcome a deepening of Canada's constitutional crisis. However, we are more concerned about the fact that constitutional interpretation continues to rest upon the colonial belief of the inherent superiority of European nations. Furthermore, it is our view that the acceptance of an inherent right to sovereignty and constitutional protection of First Nations selfgovernment, in fact, would not spell disaster. To the contrary, it would finally mark the start of equal participation by First Nations in the establishment of Canada's constitutional identity. 